\title{
An Examination of Theories on Savannasation and the Peasant- Environment Debate
}

\author{
J. A. Yaro \\ Department of Geography and Resource Development, University of Ghana, P. O. Box LG 59, Legon, \\ Accra, Ghana \\ Email: yarojoe@yahoo.com
}

\begin{abstract}
The paper examines man-environment relations in the African savanna. It argues that it is important to look at the relationship in a wider dimension involving conceptual frameworks that incorporate the dynamics of rural livelihoods, institutional factors, resource diversity, environmental variability and global influences on local socio-politico-economic landscapes. Land management decisions and investment patterns of diverse peasant representations are reflected in land use changes. Investigating these relationship has moved from the biased technocratic objective assessment of virgin lands and so-called mapping of human impacts to studies identifying the environment as an arena for synergistic interaction between 'man' economics and 'nature'. A conceptual shift to a 'people in places' paradigm allowing the experiences of people in differentiated environments to influence the analyses of social phenomena in savanna landscapes is underway. These shifts in thinking have multiple implications for designing policies for both rural development and environmental sustainability in the Ghanaian savanna. Ensuring sustainable livelihoods through institutions that grant secure and regulated access to resources, provide skills, capital and appropriate technology is key to environmental health and prosperity.
\end{abstract}

\section{Introduction}

In common parlance the concept 'environment' is a synonym for nature, emphasizing the man-nature dichotomy deliberated upon in many academic disciplines (Little, 1999). This dichotomous treatment has epistemological implications in terms of cause-effect explanations involving man and natural changes, which have not stood the test of time. The environment of a particular human group includes both cultural and biophysical elements (Little, 1999), which allows for a delimitation of a wide range of socio-natural units of analysis that transects the nature/culture division orthogonally. Fairhead \& Leach (1996) explain that, in many African societies, a distinction between nature/man is alien; categories of thought are structured in very different ways, which cross-cut a nature-culture divide.

Envisioning the environment holistically provides an avenue to subjectively analyse land use changes associated with the preferences of people living in specific geographical spaces. This new conceptuali-sation also recognises the fluidity of processes and phenomena hitherto referred to as fixed or immutable. Nature cannot be ascribed equilibrium characteristics nor can a relationship between man and nature be described as being in equilibrium using some objective criteria of carrying capacity. Emerging social dysfunction and a breakdown of any perceived culture-nature equilibrium disturbs this supposed equilibrium. Studies stressing the naïve functional organismic view of society and the inherent features of man to destabilize harmony in nature through population growth or ignorance are criticised as positivistic and simplistic reductionism (Carney \& Watts, 1991; Chambers, 1994a; Boyd \& Slaymaker, 2000; Cavendish, 2000; Agrawal, 2001; Lambin et al., 2001). This paper recognises the intertwining of man and nature in a contextual environmental situation where livelihoods consist of diverse activities dictated by man and nature. 
Peasant livelihoods are outcomes of ecological, economic and political interactions, suggesting that any one-sided analysis of processes in each of the three broad domains is bound to fail in constructing reality. Political ecology research programmes incorporating ecological concerns with wider political economy set the pace for an anthropocentric analysis of environmental issues (Blaikie, 1985; Blaikie \& Brookfield, 1987; Carney, 1992; Blaikie, 1993). Research on local knowledge from farming systems research and rural development (Boserup, 1965; Chambers, 1983; Devereux, 1999) has questioned previous views on the 'homogenous over-populating poor and ignorant opportunistic peasant' (Hardin, 1968; Ehrlich, 1971; Eckholm \& Brown, 1977; Brown, 1989; Department of Geography and Resource Development, 1992; Brown \& Hal, 1994). Based on these new revelations or ideas several authors have taken the pains to deconstruct the dominant literature on environmental degradation and policies, leading to the branding of these views as popular myths, grand narratives, alarmists, prejudiced and simplistic (Leach \& Mearns, 1996; Boyd \& Slaymaker, 2000; Cavendish, 2000; Benjaminsen, 2001).

Popular myths are 'simplifications of cause-consequence relationships that are difficult to support empirically but have gained sufficient public support to influence environmental and development policies' (Lambin et al., 2001). The prominence of the sustainable livelihood approach in contemporary peasant studies affirms the rise of anthropocentrism (Scoones, 1998). However, the conflict between structure and agency still wages on, as some stress the constraint of invisible capitalist development (Blaikie, 1985; Angelsen, 1997) while others acclaim peasant struggles and agency (Stonich, 1993). Empirical research has, however, mediated the above dichotomy by introducing the concepts of opportunities and constraints which are widely employed in the sustainable livelihood approach (Leach \& Davies, 1991; Maxwell \& Smith, 1992; Frankenberger, 1996; Leach et al., 1997) and in the globalisation literature (Zimmerer, 2007) and land use studies (McCusker \& Carr, 2006). Adopting a 'people in places' paradigm not only captures ecological and political economy concerns, but also allows an investigation and analysis using a livelihood approach that incorporates local knowledge, perceptions, history and explanations influencing the scientist's understanding of social and ecological phenomena.

The savanna vegetation covers over $41 \%$ of the land surface of Ghana. It is a source of livelihoods to $30 \%$ of the Ghanaian population, providing ecological conditions for cereals, cotton and economic trees, such as the shea and dawadawa trees. Maintaining the environmental integrity of the savanna zone has manifold implications for the Ghanaian economy. The extent to which policies in environmental management in Ghana reflect knowledge on savanna systems generally is important in avoiding mistakes in conceptualisations committed elsewhere. This article assesses evolving knowledge of causation of environmental inter-relations in the savanna environment and provides its implications for the management of the Ghanaian savanna. An examination of the concept of savanna is presented first, followed by a critique of the theories of savannasation, and the changing paradigms on man-nature interrelations. The implications of the debate for ensuring sustainability of livelihoods and environ-mental health are discussed, and the final part provides the conclusion.

\section{The savanna vegetation}

The African savanna has been a source of debate of various theories regarding its origin, current changes and peasant/nature relations. The savanna vegetation has been defined variously according to either characteristics or climate. Fairhead \& Leach (1996) define a savanna as open grassland including variable numbers of trees or shrubs but without closed canopy woodland, which burns almost every dry season. Characteris-tically, the savanna is broken down into categories depending on the region under study. For Ghana, the northern savanna has been divided into two; Guinea savanna and Sudan savanna (Ministry of Lands and Forestry, 2001). The Guinea savanna consists generally of fire tolerant, deciduous, broadleaved trees interspersed in a ground flora of mainly grass, sometimes more than $1.5 \mathrm{~m}$ high. Sudan savanna is generally of open savanna with short grass interspersed with relatively short low branching deciduous, broad and thin-leave trees.

West African Journal of Applied Ecology - Volume 13 
The difficulty of providing a definition to capture the reality of the areas referred to as savanna is reflected in the statement 'the vegetation in most of the study area is characterised by a mosaic of forest, savanna, marshes and grassland' (Ministry of Lands and Forestry, 2001) in describing the northern savanna area of Ghana. Also, in the south of the country and West Africa in general several spots are now described as derived savannas following Taylor's (1952) distinction of the original Guinea savanna vegetation and the derived one in forested areas. In this study the term savanna is limited to grasslands with or without significant tree formations. The definition covers forest savanna transition areas, Guinea savanna areas and Sudan savanna (Fig. 1).

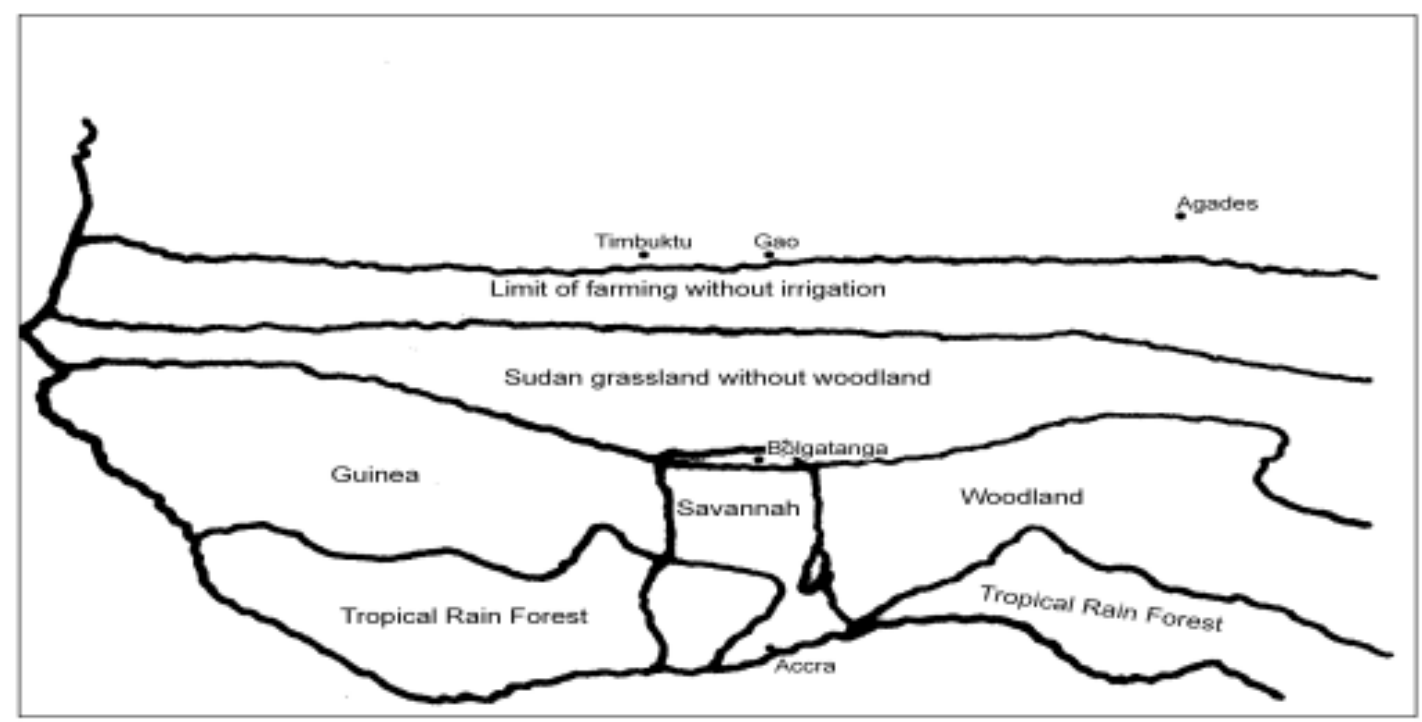

Source: Adu (1969

Fig. 1. Vegetation zones in West Africa.

\section{Savannasation narratives/discourses}

"Savannasation is the process of deterioration of forests through savanna to poor grasslands. This process is inevitably connected with deterioration of vegetation; invasion of grasses, desiccation of air and ground, sinking of the groundwater table, shortage of water for human and animal consumption and for irrigation purposes, lowering the fertility of the soil, increase of water and wind erosion; as the desert is approaching, the grass becomes shorter, tree and shrub vegetation more scarce and the ground is invaded by sand" (Korem, 1985). The above definition is in conformity with the views of the colonial administrations, the independent African governments and several environmental organisations all over contemporary Africa and the rest of the world. It is argued that there are no natural causes to savannasation, but only human causes through excess pressure on nature above its carrying capacity (Korem, 1985; Durning, 1989; Brown \& Hal, 1994).

Adu (1969) describes the original vegetation of the northern savanna as Sudanese, characterised by short deciduous trees often widely spaced and a ground flora composed of different species of grasses of varying height. Very little of the vegetation exists in its original form; owing to settlement, over population, annual and periodic fires, many areas now consist of degraded tree-savanna (Adu, 1969). Dickson \& Benneh (1970) contend that the original vegetation in the savanna was much richer, consisting

West African Journal of Applied Ecology - Volume 13 
of numerous trees. Evidence to this postulation is the remaining patches of forest, used as fetish groves. The savanna vegeta-tion has remained as it is because of continued regular burning, cultivation, and grazing by livestock (Dickson \& Benneh, 1970).

The most influential authority in accounting for savannasation process is Aubreville (Fairhead \& Leach, 1996) whose works influenced the ecological debates for over half a century. Aubreville (Fairhead \& Leach, 1996) argued that a dry season of 2-3 months were the limit of what he considered would sustain forest, but not beyond it. Deforestation by man enabled the penetration of the harmattan winds during the intense dry season, thereby, preventing tree regeneration. The relationship between climate and vegetation is seen as having positive feedbacks. Aubreville contends that deforestation dries the climate by reducing rainfall and air humidity, and by enabling the harmattan wind to penetrate further south, so creating conditions in which the forest cannot re-establish.

Aubreville also attributed derived savannas to a combination of shifting cultivation and fires. Shifting cultivators who reduced the fallow periods and through their activities enable grass invasions, which are prone to annual fires, prevent tree reestablishment in a climatic zone capable of breeding trees. These theorisations led Korem (1985) to the following conclusions on the Ghanaian environment: (1) The area under forest has been dangerously decreasing, (2) Northern savanna is rapidly expanding southwards and the coastal savanna is expanding further northwards, (3) The savanna area of Ghana is rapidly deteriorating, (4) The distance between Ghana and the Sahara Desert has been steadily decreasing, and (5) The phenomena causing these situations are mainly bush fires, shifting cultivation, improper agricultural practices and, in general, the negative attitude of people to trees (Korem 1985).

In the 1990s natural and social causes gained prominence in explaining savanna-sation process. Climate changes and socio-cultural practices, including farming systems, energy sources, road rehabilitation, and general land excavation works are the major factors of land degradation. Using this postulation as a guiding framework, Yaro (1997) associated various farming systems, land excavations, erratic rainfall and fuel wood harvesting with the increasing land degradation, using declining food production and other physical attributes as evidence. A study by the Ministry of Lands and Forestry (2001) stresses that the ecology of the northern savanna is severely altered reflecting a prolonged unregulated grazing, burning and intensive cultivation. It also states that its 72 forest reserves are under pressure from subsistence livestock herders and others who engage in illegal activities in the reserves.

Policy response to savannasation has been rigorous in all African countries, including those in the equatorial climatic zone with tropical rainforest vegetation. The following assumptions can be elicited from the savannasation orthodoxy on the man-nature relationships: (1) Originality or naturalness of vegetation formations defined by specific atmospheric conditions. (2) Any alteration not reflecting luxuriance was the cause of man. (3) Man and nature co-exist peacefully in an equilibrium where man's activities pose no danger to nature. Pressure by man through population growth and overstocking of livestock leads to disequilibrium. There is a calculable carrying capacity for all eco-systems. (4) Single pathway of causality with negative feedbacks. Man colonises nature, extracts resources which cannot regenerate because of excessive pressure, resource depletion leads to human misery that propels more extraction even of less desired species until the desert over runs the luxuriant landscape. (5) The irrationality of man. The lack of any technical knowledge on the functioning of the ecosystem by the poor over-populating peasant. (6) The tragedy of the commons rules. (7) The problem is well understood and solutions are simple and within technological reach.

\section{Paradigm shifts in theorising savanna-sation}

Kuhn (1962) describes science as evolving in a step-wise fashion: every now and then, new ideas emerge which challenge the very foundation of what was accepted as common ground. Recent evidence from land degradation research by farming systems research, political economist and neo-liberal schools contributed to such a paradigm shift. The move from closed-systems to open-systems, from simplification and reductionism to complexity and holism, from ecological processes to human processes, from peasant

West African Journal of Applied Ecology - Volume 13 
characteristics to general macro socio-economic conditions and from homogeneity to diversity has greatly changed views on the savannasation process. Savannasation from the above deliberation is basically land degradation, which encompasses all loss of intrinsic qualities of nature. Frameworks studying man-nature relations have moved from assumptions of irrational peasant or pastoralist to one supporting the image of unpredictable and multiple-equilibrium eco-systems (Biot, 1992).

The savannasation orthodoxy has been severely criticised for its non-empirical analysis, faulty assumptions, dogmatism, eurocentricism, and single hypothesis type explanations (Chambers, 1988; Blaikie, 1989; Blaikie, 1993; Stonich, 1993; Tiffen et al., 1994; Leach \& Mearns, 1996; Benjaminsen, 2001; Lambin et al., 2001; Rasmussen et al., 2001; Raynaut, 2001). According to Chambers (1983), these views emphasize physical dimensions of natural and man-made disasters, usually concentrating on interpretation in terms of what is physical, visible, technically and statistically common sense. Equilibrium ecosystems and originality of vegetation have been proven to be an idealism, which never existed and is not possible (Fairhead \& Leach, 1996; Leach \& Mearns, 1996; Leach et al., 1997; Fairhead \& Leach, 1998; Benjaminsen, 2001). Trends in natural ecology emphasizing equilibrium, homeostasis, and stability have, beginning in the 1970s, gradually shifted toward new emphasis on disturbance, catastrophe, and non-equilibrium dynamics (Little, 1999).

Notions of equilibrium allowing the calculations of carrying capacity is problematic as ecosystems are variable and dynamic, reflecting both short and long term atmospheric and human disturbances and trends. Rather, 'event driven' systems in non-equilibrium systems (Rasmussen et al., 2001) account for most changes in land-scapes. Lambin et al. (2001) contend that it is a misconception to think of rangelands as natural entities in which, in the absence of human impact, would persist unchanging within climate epochs. It is not completely wrong that some savannas are edaphically and climatically determined, but contem-porary trends in most places point to the fact that savannas are maintained in their current form by human and biophysical drivers. Forest patches in savanna areas cannot constitute enough evidence to support natural ecology since the same patches have been used by anthropocentrists to justify human agency in the creation of wood lots where they wish to have them, whether for cosmological reasons or practical utilitarian purposes.

The role of population growth in the savannasation process can be subject to various interpretations, thereby, pointing to some underlying conditions that dictate possible impacts. The Boserupian view contends that population increases stimulate innovations in agriculture in the form of technological and institutional changes (Boserup, 1965; Behnke \& Scoones, 1993; Blaikie et al., 1994). Ester Boserup's thesis of agricultural intensification recognises the ability of people to innovate, invent and adapt to difficult situations in line with the old adage that "necessity is the mother of inventions". She argues that rural people will apply inputs such as manure and other matter, change crop varieties and use new implements best suited to such environments. Population growth enables the use of more labour per unit land, which is known to produce high outputs. The theory of induced innovations (Lein, 1990) supports Boserup's view. It states that the nature of technological change in agriculture will be dependent upon society's factor endowments. Some societies are rich in capital and land, while others in labour. Under free market conditions, this will be reflected in relative factor prices. Labour would be relatively cheap in high population density areas compared to land and capital and relatively expensive in more land and capital abundant societies (Lein, 1993).

Another empirical study on deforestation, for instance, concluded as follows:

"Yet, simultaneously, population growth is not a sufficient causal explanation for the growing abuse of land, destruction of forests, soil, or other ecological problems of the region. Rather inequality in access to land and the investment patterns of large landowners, neither of which depends on population pressure, are the core of the widespread environmental destruction in the region" (Stonich, 1993)

Political and economic processes must be incorporated into the biophysical adaptive situation, not only to provide historical specificity to human/environment interaction, but also to identify factors that West African Journal of Applied Ecology - Volume 13 
'perpetuate unequal adaptive potential' (Little, 1999). Political economists, using neo-Marxist frameworks, provide a structural analysis of the man-nature relationship. Blaikie (1985) argues that landuse decisions made over time are the most crucial factors determining soil degradation. These decisions are borne out of a complex web of economic, social and political interrelationships that develop over time.

The irrationality and lack of technical knowhow attributes of peasant assigned by the savannasation theorists has been proven to be wrong, bias, subjective and very simplistic (Chambers, 1983). Rather, rural development researchers argue that; rural peoples' knowledge is often superior to that of outsiders. Examples can be found in mixed cropping, knowledge of the environment, abilities to observe and discriminate, and results of rural peoples' experiments (Chambers, 1994; Davies, 1996; Fairhead \& Leach, 1996). Many of the practices of small farmers which were once regarded as primitive or misguided are now recognised as sophisticated and appropriate (Fairhead \& Leach, 1998; Amanor, 2002).

The use of the concept of 'Ecological Marxism' (O'Brien, 1995) in the analysis of Latin American crises focused on the contradiction between the forces and relations of production, on one hand, and the ecological conditions of production, on the other. It examined theoretically and empirically the tendency of capitalist development to destroy its own ecological conditions of production - the environmental basis for maintaining dependent capitalism - thereby, aggravating economic and social crisis in the long run (Stonich, 1993). External factors are seen as the most crucial in this perspective as they alter production systems that in turn induce environmental decline. External factors in the form of inappropriate and exploitative technology and poor prices of traded items seek to justify the environmental decline being experienced in these regions. However, political economists overstressed the role of external factors in a structuralist determinist fashion that failed to recognise local level dynamics of power, entitlements and endowments, population dynamics and possible positive roles of the market in the man-nature interrelationships.

The Political Ecology concept (Fig. 2) emerged in response to the above objective of providing an integrated analysis of the man-nature relationships through the integration of both physical/human ecology and political economy (Blaikie, 1985; Blaikie \& Brookfield, 1987; Blaikie, 1989; Blaikie, 1993). The approach examines the interacting roles that social institutions (international, national, regional and local) play in providing constraints and possibilities that affect human decisions that in turn affect those institutions as well as the natural environment (Stonich, 1993). This integrated perspective has been used in a number of disciplines to show how interconnected economic, political and social processes affect the way natural resources are exploited. Analysis follows a 'chain of explanation' through different scales (levels of analysis) beginning with the decisions of local land managers (such as farmers), the interrelation among local managers and other groups in society who affect local land management, and the roles of the state and the world economy. Because political ecology insinuates analysis of structures external to local groups, which affect options and decisions, considerable attention is focused on the ways in which international capitalism and the state affect natural resources and local people (Blaikie, 1993). Political ecology advocates a bottom-up analytical approach starting with the smallest decision-making unit in the family and examining its political structure, agricultural and non-agricultural activities.

West African Journal of Applied Ecology - Volume 13 
REGIONAL POLITICAL ECOLOGY

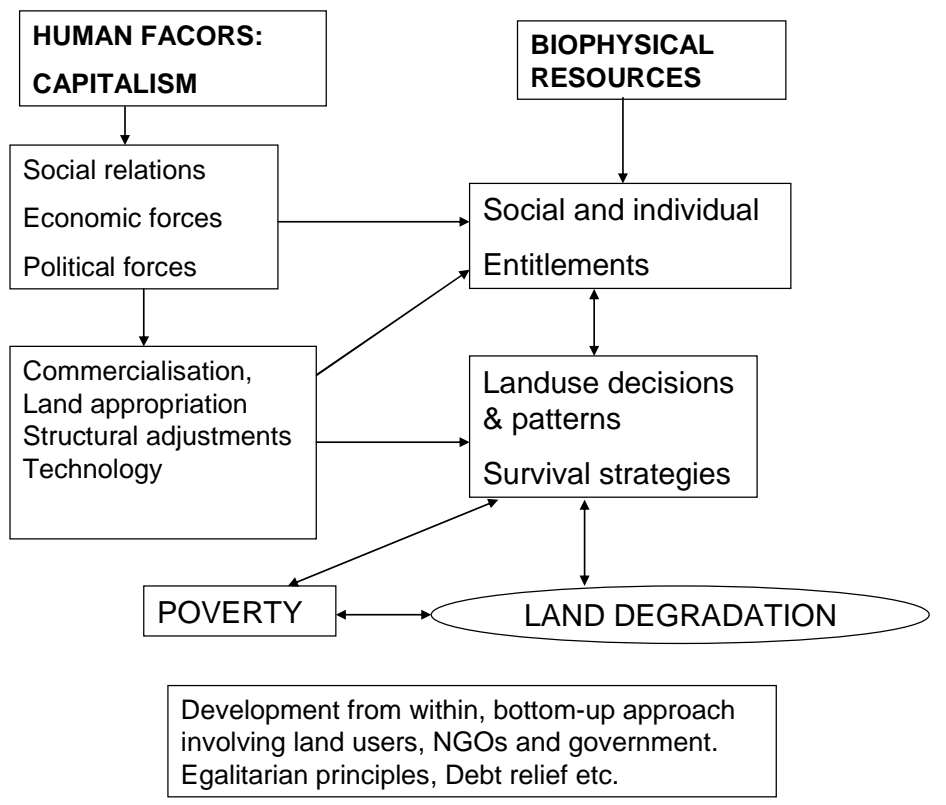

Source: Yaro 2000

Fig. 2. A Political Ecologist Framework

The political-economic structures behind the range of choices are the most important analytical steps and opens wider concerns for the local, national and international levels. Political ecology also outlines how core-periphery relations and capitalism leads to land tenure changes that cause the marginalisation of peasants into fragile ecosystems.

Small producers are displaced to less fertile or environmentally more vulnerable location because of land expropriations by the state or by large agric-businesses. Small producers are placed in a position where they may be forced to over-exploit a scarce resource in order to survive (Blaikie, 1985). The Tribal Grazing Land Policy (TGLP) in Botswana, which favours large cattle owners, has been characterised as a land grab, the taking away of large grazing areas traditionally used by small farmers (Hesselberg, 1993). According to Hesselberg (1993), the result of the above scenario is overgrazing on communal areas because large commercial ranchers have access to these and their own ranches.

Neo-liberal analysts opposing the political economist, attribute environmental degrada-tion in the tropics to faulty incentive systems affecting economic and demo-graphic behaviours centred on the use of common property resources and to "irrational traditional" (that is stagnant and using "primitive technology') landuse decisions of small producers. The market is a perfect instrument that allocates all sorts of resources in the most judicious manner possible. It argues that competition necessarily leads to appropriate manage-ment of resources. The removal of market distortions is a necessary and sufficient condition for environmental redemption (Aubynn, 1997). A reduction of the role of governments in influencing the market, the liberalisation of trade and privatisation schemes has been suggested as remedies to under-development and hence environ-mental deterioration.

Neo-liberal views have been criticised on several counts. The perfect competitive markets which are supposed to ensure a Pareto-efficient resource allocation, tend to dis/mis-allocate resources to the benefit of a few profit oriented 'rational' individuals. In response to prices of products on the markets, influential farmers go into the cultivation of crops that earn them more money using potentially 
destructive inputs such as herbicides, fertilizer, heavy tractors, etc. and environmentally unfriendly cropping systems such as monocropping. Privatisa-tion, as suggested by this view, can, thus, cause environmental degradation in two ways: one is through the rich-profit oriented individuals and companies; and the second is through the poor who resettle on marginal land or work on leased land (Angelsen, 1997; Boyo, 1997). Current neo-liberal thinking is in keeping with contemporary perception of the man-nature relationship as reflected in programmes of the World Bank for poverty reduction, food security, natural resource management and community participation and empowerment models (World Bank, 1986; World Bank, 1990; World Bank, 2000).

\section{A 'People in Places' paradigm: A liveli-hood framework}

Post-modernists and critical realists, focusing on contextual analytical frameworks that incorporate dynamism, diversity, holism and historicity have shed new light on the study of social phenomena at multiple levels. Political economists' thinking have undergone changes in response to growing criticism of the neglect of the population variable, romanticism of peasant's modes of production, unqualified generalisa-tions, neglect of markets, and the use of grand theories. There is a conceptual shift to a 'people in places' paradigm allowing the experiences of people in differentiated environments influence analysis of social phenomena (Forsyth \& Leach, 1998). The shift from a dichotomous treatment of the concept of environment to an intertwined one where nature and man interlock captures the main tenets of the people in places paradigm.

There has been an appraisal of the various wings of the man-nature relationship ranging from environmental resources, population, land tenure, soil and water conservation methods, government policy and so on, which, more than often, result in diverse ways. This has culminated in the need to disaggregate concepts under study (Reardon \& Vosti, 1995; Angelsen, 1997; Leach et al., 1997), need for application of people-based analytical frameworks (Forsyth \& Leach, 1998), choice of level of analysis (Johan, 1991; Blaikie, 1993; Frankenberger, 1996) and historical specificity (Williams, 1994; Boyd \& Slaymaker, 2000).

Savannasation, as a succession theory and its hard line carrying capacity mathema-ticians, has given way to the term land degradation and aggradation. The concept of land degradation reflects a notion of a loss of value of a resource without prior subscription of any cause. Hence, land degradation can occur in areas with or without human habitation. A people in places paradigm recognises the ability of man to both destroy or improve his natural resource base which is an intrinsic part of actively constructed livelihoods.

The man-nature relationship is conceived of through the mediation by institutions carved by power struggles, which are fuelled by the forces of globalisation, global environmental change, and national, regional and local socio-economic conditions (Blaikie, 1985; Abdulai \& Delgado, 1995; Angelsen, 1997; Holden, 1997). A first step in understanding the relationship is holistically assessing the livelihoods of peasants in specific biophysical contexts, recognizing the fact that they wish to continue making a livelihood from the resources and means of living they encounter throughout eternity. The concept of sustainable rural livelihoods examines the social dynamics of livelihoods and the interactions between the actors and the natural resource base. It is important to understand the opportunities and constraints to sustainable livelihoods. Access to endowments or environmental resources is very important in achieving entitlements, which, in turn, has repercussions for sustainable livelihoods, poverty and environ-mental quality.

Man-nature interactions are mediated by rules and norms, which are continuously changing, and reflects wider and more powerful factors such as markets, government and donor policies, weather fluctuations and other biophysical changes. Institutions and organisations responsible for maintaining sustainable livelihoods may, therefore, be functioning well or not depending on the external and internal factors that affect the local situation. The role of institutions is, however, not deterministic as the struggle between structure and agency in the social sciences show. Both can be argued to have their historical West African Journal of Applied Ecology - Volume 13 
latitudes during which one gives way to the other. Entitlement analysis has been weaved into political ecology analysis to capture local level, individual and household dynamics using well defined concepts of assets, endowments and entitlements (Leach et al., 1997). Varying entitlements to land and other resources depends on different access qualification (Sen, 1984). These entitlements are governed by political and economic institutions at various levels and define the rules of legitimacy of each household to environmental resources. Shifts in entitlement often cause the degradation of land and human resources (Loiske, 1995). The view contends that bad income opportunities, low societal capabilities and low physical capabilities of the land all contribute to a decreasing land capability (degradation), which, in turn, is closely related to increased poverty.

Environmental entitlements refer to the alternative sets of utilities derived from environmental goods and services over which social actors have legitimate effective command and which are instrumental in achieving well-being (Leach et al., 1997). The sources of environmental entitlements, wage employment and remittances, and the associated risk of loosing these entitlements are crucial in understanding livelihood strategies and vulnerability in general. Questions regarding the various entitlements, therefore, revolve around which resources and opportunities, whose resources, what constraints, and how is access to capital gained. Micro level studies would, therefore, aim at land tenure systems and capability building processes that increase the range and options of peasants to other income earning activities. The power relations within the household are relevant in capturing and explaining intra-household dynamics.

The resources available and used by the peasants should be understood in terms of their characteristics, seasonality (Chambers, 1989), use-values (Campbell et al., 2001), location (Blaikie, 1985), regenerative capacity, stationarity and storage (Blomquist et al., 1994). What is the environment composed of? Good or poor soils, grassland, forest, or semi-desert? What is seen as degradation to the peasant and the scientific community, and how do these interlock? Are colonial soil and water conservation methods the only regenerative mechanisms? Answers to these and many more questions expose the complexity of man-nature relationships and directs attention to anthropocentric frameworks that must be continually refined.

Globalisation or interconnectedness of the community to other places through markets, information, policy formulations and capital flows, among others (Lambin et al., 2001), is, increasingly altering local conditions and determining land use, ownership patterns, access patterns and social capital. The forces of globalisation with mixed positive and negative pictures affect the degree of societal coherence. This is confirmed by the differential impact of structural adjustment on different parts of the world and within countries, and on different crops and environmental resources. The export sector and export producing regions of southern Ghana performed well in terms of land investment while northern Ghanaian farmers not able to acquire costly inputs pushed the burden of adjustment onto nature (Seini, 1992; Songsore 1992; Taylor \&Mackenzie, 1992; Al-Hassan et al., 1997).

Apart from institutional changes that alter access to environmental entitlements, resource characteristics, to a large extent, determine the nature of the impact of institutions (Leach et al., 1997; Lambin et al., 2001; Raynaut, 2001). Resources with high market values normally experience sound exploitation practices and vice versa (Campbell et al., 2001). In local cycles, the stationarity and mobility of resources, and who owns them, determine the efforts made to protect them. The neglect of government planted forest and earlier NGO agro-forest projects is testimony to the delineation of the ownership factor. With good asset levels, stationary resources are well taken care of than mobile ones. Hence, the persistence of wells, trees and good compound farms as opposed to wildlife and grazing grounds which are fluid in character.

Increasing diversity and heterogeneity of the peasantry mediated by capitalism's expansionary forces in an age of globalisation imposes a limitation to the use of the category 'the poor peasant' (Yaro, 2002). Poverty is differentiated among socio-politico-economic groups within a nation, region, village and household, making it difficult to simplify any links between the concept and others. Recognition of

West African Journal of Applied Ecology - Volume 13 
poverty as a process rather than a static variable fixed by income further necessitates the need to approach cause-effect analysis with caution.

The population variable is interpreted as the demographic characteristics of the population encompassing size, structure, composition and its quality in terms of education, health and nutrition. These aspects define the interrelations between man and his environment within the larger framework of sustainable livelihoods. Land scarcity as seen earlier does not always trigger inappropriate land management strategies but could also lead to productive and efficient landuse patterns. Pressure on agricultural land is now recognised as emanating from varying sources including urbanization, which might impinge directly or through market forces. Safety valves for land pressure in peasant societies are proliferating through non-farm activities that provide sources of livelihood to households. Hence, assuming the concept carrying capacity was mathematically applicable, it would still be difficult to determine the pressure exerted by the total population of peasants occupying a geographical area since each member has a portfolio of livelihood activities that might not use the natural resource base.

\section{Implications of changing paradigms for sustainable livelihoods and environmental management in the Ghanaian savanna}

The Ghanaian savanna is said to be increasing in size and subsuming, hitherto, forestland. At the same time the quality of the savanna in terms of providing environ-mental services is falling as land degradation takes hold in many places. Crop cultivation through extensification spurred by market and population pressure represents the major point of contact with nature. Ensuring environmental sustainability in terms of continuous extraction of environmental goods for human use without compromising future generations' access to them is a major challenge. At the same time, ensuring that rural people who inhabit the savanna carve out sustainable lives using these environ-mental goods is a major developmental policy objective of governments.

An important lesson to be learnt from the savannasation discourse is that the era of "nature environmentalism' is gone. There is an awakening to a new dawn of 'people environmentalism'. How does one ensure a positive synergy between man and nature in the savanna? Economic growth in the era of globalisation is making many governments in the developing world turn a blind eye to the destructive effects of resource extraction. How does one balance the two extreme positions? Cues from the debates are necessary tools in current environmental and livelihood modelling.

Creating an environmental awareness within a learning paradigm is an important first step in disseminating and understanding the nature of the Ghanaian savanna. The scientist's knowledge of the physiographic processes is often thought to be higher than that of the local farmer or resource users. This thinking relegates and denies the scientist from tapping the store of knowledge and skills that local resource users have accumulated over the years. The scientist may have laboratory-based empirical proof, but the local resource users have a wealth of empirical historical evidence of how nature responds to their trials. Collaborative efforts aimed at understanding, learning and disseminating environmentally friendly behaviours is crucial in achieving sustainable livelihoods outside the language of coercion that has never produced meaningful results.

The creation of a Savanna Ecological Commission is important in endogenising the scattered functions of organisations that currently are biased towards forest and food production such as the Ministry of Agriculture, Forestry Commission and Environmental Protection Agency. A Savanna Ecological Commission should play the functions of research, regulation and coordination, and organise stakeholders within local government structures to disseminate findings, negotiate institutional rules, harmonize policies and demonstrate with proof the 'hows and whys' of their propositions rather than impose foreign notions and political idiosyncrasies. Care should be taken not to make it a mere salarypaying institution, but one committed and backed by financial and statutory support.

The environment is not a separate sphere of life, but an embodiment and, sometimes, a determinant of life. Development planning cannot operate only in the realms of economics, but must integrate environmental and cultural aspects since livelihoods subsume the history, economics, politics, West African Journal of Applied Ecology - Volume 13 
culture and environments of societies. Planning holistically is not the suggestion here. Thinking should assume a systems dimension teasing out the effects of an introduction of a propulsive agent and how that relates and acts on other aspects of the integrated system. The haphazard introduc-tion of innovations by different ministries such as Economic Planning, Local Government, Agriculture and Rural Development, and the Environmental Protection Agency needs harmonisation based on a negotiated knowledge of the environment with local resource users. There is a practical difficulty here since these agencies, at the core of policy formulation, are often pre-occupied with broad-based national policies. The evident solution becomes a translation of these national level visions of development by local governments into realistic integrated planning projects that are co-managed by local people.

The trade-offs identified under the livelihoods perspectives is adequate warning of the impending danger social inequalities can pose to the realisation of sound environmental practices. Inherent dilemmas in carving livelihoods are real. Such dilemmas need state and international collaboration with enough goodwill to deal with. The role of politics is crucial here as any decision taken is purely political rather than based on best fit solution since it would involve choices between practices used by different people on natural resources, and the inclination of ruling classes towards one group means opposing the other. The thinking is mostly human-centred, that is, geared towards the utilitarian perspective of nature to man, rather than man to nature. The danger of the livelihoods perspective is to always consider man supreme in the equation with minimal attention to the environment. Considerable effort needs to be made at tradeoffs that seek a minimalist consumption philosophy so as to allow the regenerative capacity of nature continue to provide resources for future generations.

The notion of economic growth currently obviates this philosophy and destroys its own underlying ecological basis. Many would continue to live in a desperate ecocide of poverty. Should economic growth be viewed only through the lens of inter-nationally measurable gross domestic product? Care needs to be exercised in order bit to attain laureates that domestically pose problems of unsustainable conditions that directly impact millions of poor people and indirectly impact the higher classes that live off the proceeds of such growth. Satisfaction of human needs, not along the erstwhile basic needs approach, but along secure livelihood approaches with minimalist formulations must constitute the principal objective of governments and the international governance institutions.

Increasingly, a call is being made to diversify rural livelihoods away from agriculture and also to a major urbanisation drive geared towards reducing the pressures on nature. Evidence emerging seems to suggest some positive implications both for reducing poverty and ensuring environmental quality. As observed in the arguments in the theories, man is a necessary corollary of environmental management, but his ubiquitous presence can constrain environ-mental quality. Though this argument has been informed by an 'Absolute Malthusian' notion, it is argued that adapting it to a 'Relativist Malthusian' notion, which is not informed by numbers of environmental resource-users but by the type, level and intensity of livelihood activities, helps inform when and where nature needs a break. Economic activities can be sequenced with food, horticultural and perennial crops replacing each other and occupying different components of the landscape, according to the dictates of the market and ecological conditions. Intensive use of the savanna of Ghana is a possibility, but one that needs natural regenerative measures aided by organic rather than inorganic land improvements. Creating an organic culture in the northern savanna should not be difficult to achieve since livestock, which actually serves as a life-saver for many thrives well but for lack of state support to this sector it is dying.

Counter arguments would the unsus-tainable practices associated with large herds on a fragile savanna ecosystem. It has been shown that even in the Sahel many grass species have the capacity to grow fast enough, that hardly do grasslands become deserts as a result of animal rearing, and also livestock rearing serves a biological recycling and nutrient-fixing mechanism for the environment, further, leading to grass and other plant growth. Droughts that cause dried landscapes and desert conditions are creations of forces that are worldwide in causation rather than localised, even though discrete local conditions contribute to their global reach. Small experiments by NGOs in northern Ghana West African Journal of Applied Ecology - Volume 13 
on intensive livestock rearing provides good micro evidence on its twin benefits of providing milk and meat to the market, which saves the country of foreign exchange, provides income to the farmer, provides organic manure to compound farms, which in turn increases crop yields with beneficial consequences to livelihood security and the strangling of the 'ecocide of the peasant'. Economic engineering is a necessary condition for controlling market forces which determine the behaviour of people, and states can control the process through the provision of micro-credit, extension services, advice and avenues for a shift to non-agricultural livelihoods.

Enhancing livelihood security and savanna sustainability are achievable objective, one that falls in line with the national objective of achieving the millennium development goals, but one that needs local solutions aided by national policies which are constructed, taking into consideration past mistakes on environmental and developmental theorising and recognising emerging thinking on man-environment and political economy relations.

\section{Conclusion}

The savannasation theory has been narrow, eco-centric, and circular-causative in its construction of landscape change while neglecting wider politico-economic processes that construct the contours of power in communities. The paper shows alternative representations of the processes and philosophical strands of knowledge that better describe landscape changes and show how access to environmental resources by a diverse peasantry with dynamic livelihood pathways represents a new paradigm emerging in the social sciences. The shift from things to people in the rural develop-ment literature influenced by practioners in the field has greatly elevated the anthro-pocentric school of thought on environment, which subscribes to the use value of land resources rather than originality or 'naturality' of nature.

Man/nature relations are realistically and materialistically highly political and economic. For any man or woman to interact with nature, access qualifications are needed from a hierarchical social organisation whose relations are based on power. Relations of production and reproduction of the material base of society depend on the use of power that is increasingly becoming globalised. A 'people in places' paradigm identifies multiple realities in differentiated places with diversified groups of people under varying forces, be they local, national, or global.

The changing paradigms and new epistemological considerations form a solid background for changes in policy geared towards achieving developmental and environmental goals. In this regard, the paper identifies a negotiated effort at understanding environmental and developmental problems with local resource users, as a basic first step to state policy formulations. The savanna with its unique fragile ecological system, needs special initiatives that stresses organic regenerative versus artificial regenerative mechanisms. Ecological and economic science needs a local twist to achieve the twin objectives of enhancing human well-being and sustaining the savanna, which requires a good under-standing of the dilemmas that achieving these objectives entail. It is argued that the key to achieving these laudable objectives lie within the purview of the state which, to a large extent, has control over mechanisms that can alter demand and supply conditions, provide basic needs and sensitise people using the local government institutions. However, development and environment issues are dynamic and there is the need to be careful and seek new knowledge, as the set of conditions that guide both environmental and human behaviour keep changing, thereby, posing problems to long-term environmental and developmental planning.

\section{References}

Abdulai C. and Delgado C. L. (1995). Re-establishing agriculture as a priority for policy in Sub-Saharan Africa. International Food Policy Research Institute. Washington D.C.

Agrawal A. (2001). Common property institutions and sustainable governance of resources. Wld Dev. 29(10): 1649-1672.

Al-Hassan R., Famiyeh J. A. and Jager A. D. (1997). Farm Household Strategies for Food Security in Northern Ghana: A Comparative Analysis of High and Low Population Farming Systems. In Sustainable food security in West Africa. (A. Okyere, G. Benneh and W. Tims, ed.), pp. 130-152. Kluwer Academic Publishers, London.

West African Journal of Applied Ecology - Volume 13 
Amanor K. (2002). Shifting Tradition: Forest resource tenure in Ghana. In The Dynamics of Resource Tenure in West Africa. (C. Toulmin, P. L. Delville and S. Traore, ed.), pp. 48-61. IIED, Oxford.

Angelsen A. (1997). The poverty-environment thesis: Was Brundtland wrong? Forum Dev. Stud. 1: 135-154.

Behnke R. H. and Scoones I. (1993). Rethinking range ecology: implications for rangeland management in Africa. In Range ecology and disequilibrium - New models of natural variability and pastoral adaptation in African savannas. $(\mathrm{R}$. H. Behnke, I. Scoones and C. Kerven, ed.) Overseas Development Institute \& IIED, London.

Benjaminsen T. A. (2001). The population-agriculture-environment nexus in the Malian cotton zone. Global envir. Change 11: $283-295$.

Biot I. (1992). What is the problem? An essay on land degradation, science and development in Sub-Saharan Africa. Discussion paper, School of Development Studies, University of East Anglia.

Blaikie P. (1985). The political economy of soil erosion in developing countries. Longman, London.

Blaikie P. (1989). Environment and access to resources in Africa. Coping with Land degradation. Africa 59(1): 19-39.

Blaikie P. (1993). The "Chain of Explanation" in Land Degradation. In A discussion on natural resources research in the Third World. (C. Christiansson, ed.), pp. 27-39. Stockholm University, School of Geography, Environment and Development Studies Unit (EDSU), Stockholm.

Blaikie P. and Brookfield H. (1987). Land degradation and society. Methuen, London.

Blaikie P., Cannon T., Davis I. and Wisner B. (1994). At Risk. Natural Hazards, People's Vulnerability and Disasters. Routledge, London.

Blomquist W., Schlager E., Tang S. T. and Ostrom E. (1994). Regularities from the field and possible explanations. In Rules, games, and common pool resources. (E. R. Ostrom, R. Gardner and J. Walker, ed.), pp. 301-316. University of Michigan Press, Ann Arbor.

Boserup E. (1965). The conditions of agricultural growth: the economics of agrarian change under population pressure. Aldine Publishing Company, Chicago.

Boyd C. and Slaymaker T. (2000). Re-examining the 'More people less erosion' hypothesis: Special case or wider trend? Overseas Development Agency. London.

Boyo J. (1997). Structural Adjustment and the Environment: A review of Studies with Emphasis on Sub-Saharan Africa. For. Dev. Stud. 1: 59-74.

Brown L. R. (1989). State of the world 1989: A World Watch Institute report on progress towards a sustainable society. Norton, New York.

Brown L. R. and Hal K. (1994). Full house- Reassessing the earth's population carrying capacity. W. W. Norton and Company, New York.

Campbell B., Mandondo A., Nemarundwe N., Sithole B., de Jong W., Luckert M. and Matose F. (2001). Challenges to proponents of common property resource systems: Despairing voices from the social forests of Zimbabwe. Wld Dev. 29(4): 589-600.

Carney J. (1992). Peasant women and economic transformation in The Gambia. Development and Change 23(2): 67-90.

Carney J. and Watts M. (1991). Disciplining women? Rice, mechanisation, and the evolution of Mandinka gender relations in Senegambia. J.Cult. Soc. 16(4): 651-681

Cavendish W. (2000). Empirical regularities in the poverty-environment relationship of rural households: Evidence from Zimbabwe. Wld Dev. 28(11): 1979-2003.

Chambers R. (1983). Rural development. Putting the last first. Longman, London.

Chambers R. (1988). Sustainable rural livelihoods: A key for People, Environment and Development. In The greening of aid. (C. Conroy and M. Litvinoff, ed.) Earthscan, London.

Chambers R. (1989). Editorial Introduction: Vulnerability, Coping and Policy. IDS Bull. 20: 1-8.

Chambers R. (1994). Paradigm shift and the practice of participatory research and development. IDS Working Paper 2. Institute of Development Studies. London.

Chambers R. (1994). The poor and the environment. Whose reality counts. IDS Working Paper. 3.

Davies S. (1996). Adaptable livelihoods: Coping with food insecurity in the Malian Sahel. Macmillan Press, Houndmills.

Department of Geography and Resource Development (1992). A socio-economic survey in the Upper East Region with reference to drought and desertification control in Ghana. Final report submitted to the Environmental Protection Agency of Ghana. University of Ghana, Legon.

Devereux S. (1999). Making less last longer: Informal safety nets in Malawi. Institute of Development Studies. Discussion paper. 373.

Dickson B. K. and Benneh G. (1970). A New Geography of Ghana. Longman, London.

Durning B. A. (1989). Poverty and the environment. Reversing the downward spiral. Wld Watch Pap. 92.

Eckholm E. and Brown R. L. (1977). Spreading deserts: the hand of man. World Watch paper. World Watch Institute, Washington, D.C.

Ehrlich P. R. (1971). The population bomb. Balantine Books, New York.

West African Journal of Applied Ecology - Volume 13 
Fairhead J. and Leach M. (1996). Misreading the African landscape. Society and ecology in a forest-savanna mosaic. Cambridge University Press, Cambridge.

Fairhead J. and Leach M. (1998). Reframing Deforestation. Global analyses and local realities: Studies in West Africa. Global Environmental Change Series. Routledge, London and New York.

Forsyth T. and Leach M. (1998). Poverty and environment. Priorities for research and policy. An overview study prepared for the UNDP and EC. Institute of Development Studies, Sussex.

Frankenberger T. R. (1996). Measuring household livelihood security: an approach for reducing absolute poverty. The Applied Anthropology Meetings. March 27-30, 1996. Baltimore Md.

Hardin G. J. (1968). The tragedy of the commons. Science. 162: 1243-8.

Hesselberg J. (1993). Food Security in Botswana. Norsk geogr. Tidsskr. 47(4): 183-196.

Holden S. T. (1997). Adjustment Policies, Peasant Household Resource Allocation and Deforestation in Northern Zambia. An overview and some policy conclusions. Forum Dev. Stud. 1: 117-135.

Johan H. (1991). Poverty, Environment and Development: Proposal for action. SIDA \& IIED, London.

Korem A. (1985). Bush Fire and Agricultural Development in Ghana. Ghana Publishing Corporation, Tema.

Kuhn T. S. (1962). The Structure of Scientific Revolutions. University of Chicago Press, Chicago.

Lambin E. F., Turner B. L., Geist H. J., Agbola S. B., Angelsen A., Bruce J. W., Coomes O. T., Dirzo R., Fischer G., Folke C., George P. S., Homewood K., Imbernon J., Leemans R., Li X., Moran E. F., Mortimore M., Ramakrishnan P. S., Richards J. F., Skånes H., Steffen W., Stone G. D., Svedin U., Veldkamp T. A., Vogel C. and Xu J. (2001). The causes of land-cover change: moving beyond the myths. Global envir. Change. 11: 261-269.

Leach M. and Davies S. (1991). Food security and the environment: conflict or complimentarity? IDS Discussion Paper 285. Sussex.

Leach M. and Mearns R. (1996). The lie of the land. Challenging received wisdom on the African environment. Villiers Publication, London.

Leach M., Mearns R. and Scoones I. (1997). Environmental entitlements: a framework for understanding the institutional dynamics of environmental change. Institute of Development Studies, Discussion paper 359. Brighton.

Lein H. (1993). Floods and agricultural change. Some observations from Bangladesh: 1986-1990. Norwe. J. Geo. 4: 30-47.

Little P. E. (1999). Environments and environ-mentalisms in anthropological research: Facing a new millenium. A. Rev. Anthrop. 28: 253-84.

Loiske V. (1995). The village that vanished. Department of Human Geography. Stockholm University, Stockholm.

Maxwell S. and Smith M. (1992). Household food security: A conceptual review. In Household food security: Concepts, Indicators, Measurements: A technical review.(S. Maxwell and T. R. Frankenberger, eds.), pp. 1-72. UNICEF and IFAD, New York.

McCusker B. and Carr E. R. (2006). The co-production of livelihoods and land use change: Case studies from South Africa and Ghana. Geoforum. 37: 790-804.

Ministry of Lands and Forestry (2001). Environmental Assessment of Northern Savanna Biodioversity Conservation Project $(N S B C P)$. Draft. Ministry of Lands and Forestry, Accra, Republic of Ghana.

O'Brien K. L. (1995). Deforestation and Climate Change in Selva Lacandona of Chiapas, Mexico: Some preliminary results. Norsk geogr. Tidsskr. 49(3): 105-122.

Rasmussen K., Fog B. and Madsen E. J. (2001). Desertification in reverse? Observation from northern Burkina Faso. Global envir. Change 11: 271-282.

Raynaut C. (2001). Societies and nature in the Sahel: Ecological diversity and social dynamics. Global envir. Change 11: 9-18.

Reardon T. and Vosti A. S. (1995). Links between rural poverty and the environment in developing countries: Asset categories and investment poverty. Wld Dev. 23(9): 1495-1506.

Scoones I. (1998). Sustainable rural livelihoods: A framework for analysis. IDS Working paper 72.

Seini W. A. (1992). Planning for agricultural growth under policies of structural adjustment in Sub-Saharan Africa. In Planning African growth and development. Some current issues.(E. Aryeetey, ed.), pp. 171-192. ISSER/UNDP, Accra.

Sen A. (1984). 'Rights and capabilities'. In Resources, values and development.(A. Sen, ed.), pp. 307-324. Basil Blackwell, Oxford.

Songsore J. (1992). The ERP/Structural Adjustment Programme: Their likely impacts on the "Distant" Rural Poor in Northern Ghana. In Planning African Growth and Development. Some current issues. (A. Ernest, ed.), pp. 154-170. ISSER/UNDP, Accra.

Stonich S. C. (1993). I am destroying the land!: the political ecology of poverty and environmental destruction in Honduras. Westview Press, Boulder, Co.

Taylor C. J. (1952). The vegetation Zones of the Gold Coast. For. Dep. Bull. 4.

Taylor D. R. F. and Mackenzie F.,(ed.) (1992). Development from within. Survival in rural Africa. Routledge, London and New York.

Tiffen M. (1994). More people, less erosion: Environmental recovery in Kenya. Wiley Publishers.

Williams M. (1994). The relations of environmental history and historical geography. J. hist. Geogr. 20: 3-21.

West African Journal of Applied Ecology - Volume 13 
World Bank (1986). Poverty and Hunger. Issues and options for food security in Developing countries. Washington DC.

World Bank (1990). World Development Report 1990. Oxford University Press, New York.

World Bank (2000). World Development Report 2000/2001. Oxford University Press, New York.

Yaro J. A. (1997). Land degradation in the Chogu-Tishigu constituency and its effects on food production. Department of Geography and Resource Development. University of Ghana, Legon, Accra.

Yaro J. A. (2002). The Poor Peasant: One label, different lives. The dynamics of rural livelihood strategies in the Gia-Kajelo community, Northern Ghana. Norsk geogr. Tidsskr 56(1): 10-20.

Zimmerer K. (2007). Agriculture, livelihoods and globalisation: the analysis of the new trajectories (avoidance of just-so stories) of human-environment change and conservation. Agr. Hum. Val. 24: 9-16.

West African Journal of Applied Ecology - Volume 13 